\title{
The Effectiveness of the Learning Strategy of Thinking Ability Improvement (SPPKB) to Enhance Students' Higher Order Thinking Skill (HOTS) in Economics Learning at SMA 1 Kawedanan Magetan
}

\author{
Sudarmiani \\ Department of Social Science Education, Faculty of Teacher Training and Education, PGRI Madiun University, Central Java, 24355, Indonesia \\ hassan.ashari94@gmail.com \\ ${ }^{*}$ Corresponding Author \\ Whatsapp Number [081991672253]
}

How to Cite : Sudarmiani, S. (2020). The Effectiveness of the Learning Strategy of Thinking Ability Improvement (SPPKB) to Enhance Students' Higher Order Thinking Skill (HOTS) in Economics Learning at SMA 1 Kawedanan Magetan. International Journal for Educational and Vocational Studies, 2 (8), 697-701. DOI:

https://doi.org/10.29103/ijevs.v2i8.2690

\section{ARTICLE HISTORY}

Received: 4 June 2020

Revised: 11 July 2020

Accepted: 17 July 2020

KEYWORDS

Learning Strategy;

Thinking Ability Improvement;

Higher Order Thinking Skills;

Economics Learning;

\begin{abstract}
The study's purpose was to investigate the effectiveness of Learning Strategy of Thinking Ability Improvement (SPPKB) application used to improve Higher Order Thinking Skills (HOTS) of social study (IPS) students in economics learning. The research method used a quasi-experimental method with pretest-posttest control group design and effectiveness data analysis using a t-test. The research populations were 1-eleventh grade social study class (XI IPS 1) having 25 students as the experimental class and 2-eleventh grade social study (XI IPS 2) class having 27 students as the control class. The different treatment between the two classes was that in the experimental class applied the SPPKB model while the control class employed the conventional learning model. The study results reveal that the use of SPPKB has never been implemented in economics learning in the classroom. The effectiveness of using the SPPKB shows the values of the t-test results for Higher Order Thinking Skills (HOTS) abilities with significance values of $0.000<0.05$. These results indicate that there is a significant influence on the SPPKB implementation to enhance students' Higher Order Thinking Skills (HOTS) in economics learning.
\end{abstract}

This is an open access article under the CC-BY-SA license.

\section{INTRODUCTION}

Based on Act of the Republic of Indonesia, the number of 20, the year of 2003, on National Education System, that national education functions to develop the capabilities and to shape the character and a dignified nation's civilization in order to educate the life of the nation, aiming at developing the potential of students to become human beings who believe in and fear God, have noble, healthy, knowledgeable, capable, creative, independent, and being a democratic and responsible citizen. From that regulation, it is clear that the purpose of education in Indonesia is to develop the ability of students in an effort to enhance the quality of education. Meanwhile, the development of the students' abilities can be practiced and implemented through a learning process in the classroom by paying attention to the needs of students in the future.

In the 2013 curriculum, which is the foundation of the learning system in Indonesia, teachers can give opportunities to the students to be more active in developing their competencies via a learning process that is oriented towards students. One of the goals of the government about learning systems in the classroom is the development of learning oriented to Higher Order Thinking Skills (HOTS) as an effort to improve learning and graduate quality (DG GTK, 2018). Thru this program, students are expected to achieve various competencies with HOTS which encompass critical thinking, creativity and innovation, communication skills, cooperation ability, and self-confidence.

However, in reality, based on TIMSS data, it shows that the high-level thinking skills of students in Indonesia are still relatively low. This happens because, in the learning process in the classroom, students are less trained to gain higher-order thinking skills (Pratiwi \& Fasha, 2015). The results of preliminary studies in schools 
show that in the economics learning process in class, teachers still apply the conventional learning model. In that model, students only listen and re-memorize the material given, so that the economic learning process seems less meaningful and does not practice the students' HOTS.

In the process of economics learning in schools, teachers often employ a centralized learning model. This due to they still find it difficult to transition the traditional learning models into learning models that can evolve students' HOTS involving cognitive, affective, and psychomotor aspects (Ratna \& Suparno, 2017).

Meanwhile, the problem often faced by the world of education, especially in the economic learning process in the classroom, is the problem of the weakness in the teaching and learning process. During this time, students are less encouraged to expand their thinking skills especially HOTS. The learning process taking place in the class is only directed at the ability of students to memorize and repeat the information or material delivered (Rizka \& Hanggara, 2018).

Higher Order Thinking Skills (HOTS) are the skills to connect, to manipulate, and to transform the knowledge and the experience of the students in order to think critically and creatively (Yusuf, 2018). The HOTS are not the skills to memorize and to re-convey information, but it is the thinking skills used to determine decisions and problem solving on a new condition. The Higher Order Thinking Skills (HOTS) contains problem-solving, critical thinking, creative thinking, argumentation, and decision-making abilities. It is one of the important competencies in the modern world of education so that HOTS must be owned by every student (Ahmad \& Sukiman, 2019).

Therefore, higher-order thinking activities are very important to broaden students' thinking skills in finding new challenges in the learning process and outcomes (Heong, 2011). Based on Bloom's taxonomy, there are thinking levels (cognitive) from low to high levels. Three aspects in the cognitive realm are part of HOTS i.e. the analysis phase (C4), the evaluation stage (C5), and the creation phase (C6). Meanwhile, three other stages include the stages of remembering (C1), understanding (C2), and applying (C3). The applying stage is the stage of low-level thinking or lower order thinking (Sani, 2015). One learning model that can instruct and gain students' higher-order thinking skills in the learning process in class is the Learning Strategy model of Thinking Ability Improvement (SPPKB).

SPPKB is a learning model that concentrates on increasing students' thinking skills through the study of facts or based on experiences as a material to solve the problems raised. This model has three main characteristics, namely: the learning process that emphasizes the mental processes of learners to the fullest; the learning that is built in a dialogic nuance and question-answer process continuously; and relying on two sides that are equally important between the process side and learning outcomes (Sanjaya,2008). The SPPKB model is a student-oriented model and the learning model used to hone students' higher-order thinking skills.

The SPPKB has six stages including the orientation phase, the tracking stage, the confrontation stage, the inquiry stage, the accommodation stage, and the transfer stage. The last stage is the stage presenting a new problem that is relevant to the problem that has been faced by students. At this stage, students must be able to transfer their thinking skills in solving new problems through materials or learning evaluation questions provided (Sanjaya, 2008).

In the utilization of SPPKB, students play an active role in each learning process by exploring their own experiences; learning is always associated with real-life (Zayyadi, 2014). On the other hand, the advantage of this model is that students feel happy in the teaching and learning process in the classroom. Students are given the freedom to think and to express their ideas so that the knowledge they have is always developing with the experience they have.

Through the SPPKB application, learning in the classroom will be more meaningful because it prioritizes the characteristics, experiences, and basic knowledge of students via discussion and question-answer activities. On the other hand, students are not only limited to understanding learning material but also can develop the students' HOTS in solving given problems (Marniawati, 2019).

Based on the problems in the economics learning process, this study aims to observe the effectiveness of the application of Thinking Ability Improvement Learning Strategy (SPPKB) model in economics learning in high school. The SPPKB targets to educate and to enhance the abilities of Higher Order Thinking Skills (HOTS) for students in senior high school (SMA 1 Kawedanan Magetan).

\section{METHODS}

The experimental research was a type of research used to see the effect of treatments that had been determined under controlled conditions. The research was taken to observe the effectiveness of using SPPKB to advance students' HOTS in economic learning (Sugiyono, 2015). The research design exploited was a pretest-posttest control group design purposed to understand the students' abilities, before and after treatment (Sugiyono, 2015). The study was conducted at Kawedanan Magetan 1 High School (SMA 1 Kawedanan Magetan). The samples were social study classes those were 1-eleventh grade social study class (XI IPS 1) as an experimental class and 2-eleventh grade social study class (XI IPS 2) as a control class. Meanwhile, the variables in the study were the Learning Strategy model of Thinking Ability Improvement (SPPKB) as an independent variable and students' Higher Order Thinking Skills (HOTS) as a dependent variable. Data collection techniques performed 
observation, documentation, and test technique. The effectiveness test used pretest and posttest as Equation 1.

$$
O_{1} \quad \mathrm{X} \quad O_{2}
$$

$O_{1}=$ pretest value (before treatment)

$\mathrm{O}_{2}=$ posttest value (after treatment)

The research instrument took 20 items multiple-choice questions that had been tested for the validity and reliability using the Discrimination Power Index formula and the KR-20 formula, respectively. Besides, the t-test was performed to see the effectiveness of SPPKB used to improve the students' HOTS in economic learning by comparing the results of the experimental class and the control class and analyzing the students' conditions before and after being treated with the following equation uation 2).

$$
\frac{X_{1}-X_{2}}{\sqrt{\left(\frac{\sum X 1^{2}+\sum X 2^{2}}{n 1+n 2-2}\right)\left(\frac{1}{n 1}+\frac{1}{n 2}\right)}}
$$

\begin{tabular}{|c|c|c|c|c|}
\hline & The test & Type of the test & Sig. & Conclusion \\
\hline \multirow[t]{3}{*}{ 1) } & Normality test & & & \\
\hline & Control Pretest & \multirow[b]{2}{*}{ Kolmogorov-Smirnov } & $0.973>0.05$ & \multirow{2}{*}{$\begin{array}{l}\text { Pretest data from the control and } \\
\text { the experimental classes are } \\
\text { normally distributed because the } \\
\text { significance values is }>0.05\end{array}$} \\
\hline & Experiment Pretest & & $0.995>0.05$ & \\
\hline 2) & Homogeneity test & Levene Statistic & $0.312>0.05$ & $\begin{array}{l}\text { Pretest values data of the control } \\
\text { and the experimental classes are } \\
\text { homogenous }\end{array}$ \\
\hline 3) & $\begin{array}{l}\text { Equivalence test of pretest values } \\
\text { between the control and the } \\
\text { experimental classes }\end{array}$ & $\begin{array}{c}\text { Independent sample } t \\
\text { test }\end{array}$ & $0.160>0.05$ & $\begin{array}{l}\text { The two classes have the same } \\
\text { initial ability }\end{array}$ \\
\hline
\end{tabular}

Table 1. The equivalence test results of students' HOTS in the experimental class and the control class

\begin{tabular}{|c|c|c|c|c|c|c|c|c|}
\hline 4) & The Test & 5) & Type of the Test & & $6)$ & Sig. & 7) & Inference \\
\hline 8) & Improvement test of HOTS & 9) & $\begin{array}{l}\text { Independent } \\
\text { t-test }\end{array}$ & sample & 10) & $0.001<0.05$ & 11) & $\begin{array}{l}\text { There is an improvement } \\
\text { in HOTS, before and after } \\
\text { treatment. }\end{array}$ \\
\hline
\end{tabular}

Table 2. The summary of improvement test of students' HOTS skills

The different treatment between the experimental class and the control class results in an increase in students' HOTS as shown in Figure 1.

The next stage is the improvement test aimed at knowing the effectiveness of the SPPKB application to improve students' HOTS in economic learning in the experimental class and the control class. The t-test with independent sample t-test analysis was used to test the average difference between the two groups in pairs (Priyatno, 2014). The test functions to find out the differences in the average enhancement in students' HOTS.

The tests series carried out involve the normality test, homogeneity test, and t-test of independent sample t-test. Table 2 is a summary of the improvement test results of the students' HOTS. 


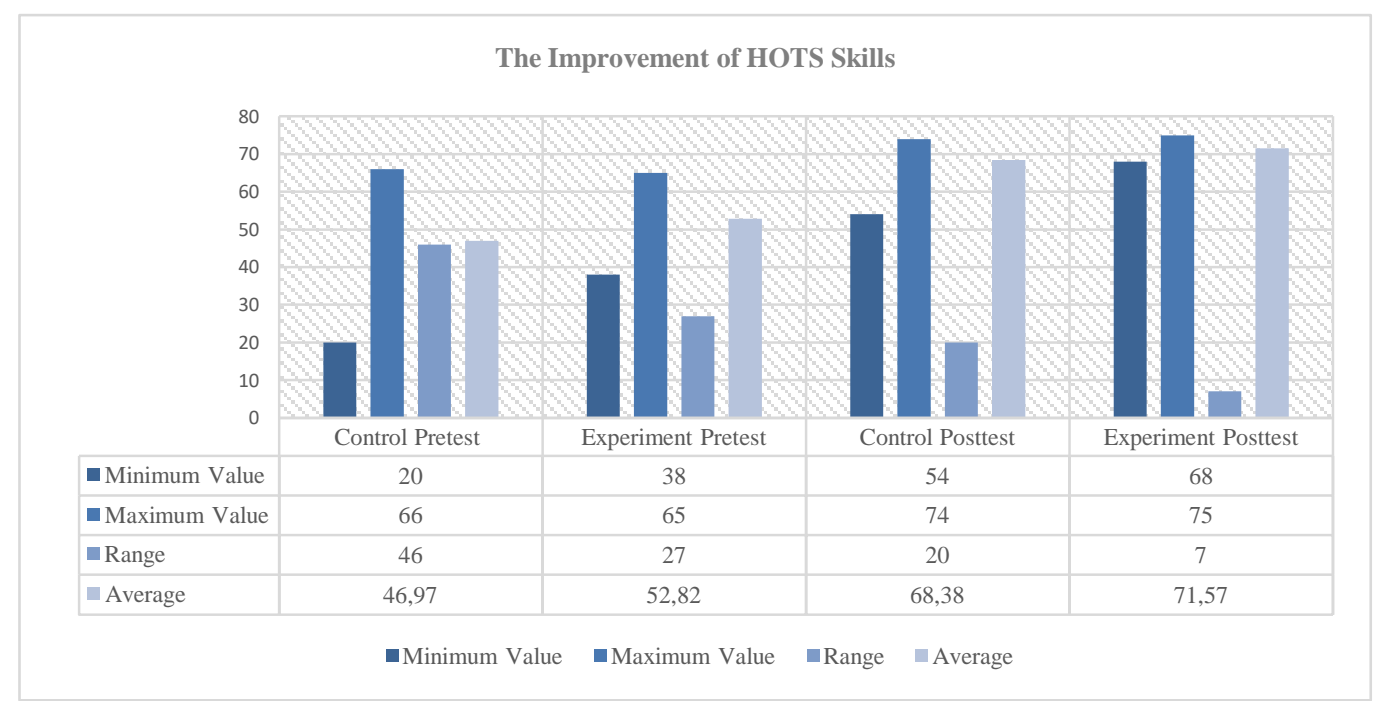

Figure 1. The pretest and posttest values of the HOTS of the experimental class and the control class

The estimation results of the students' HOTS improvement in the experimental class and the control class can be seen in Figure 2 .

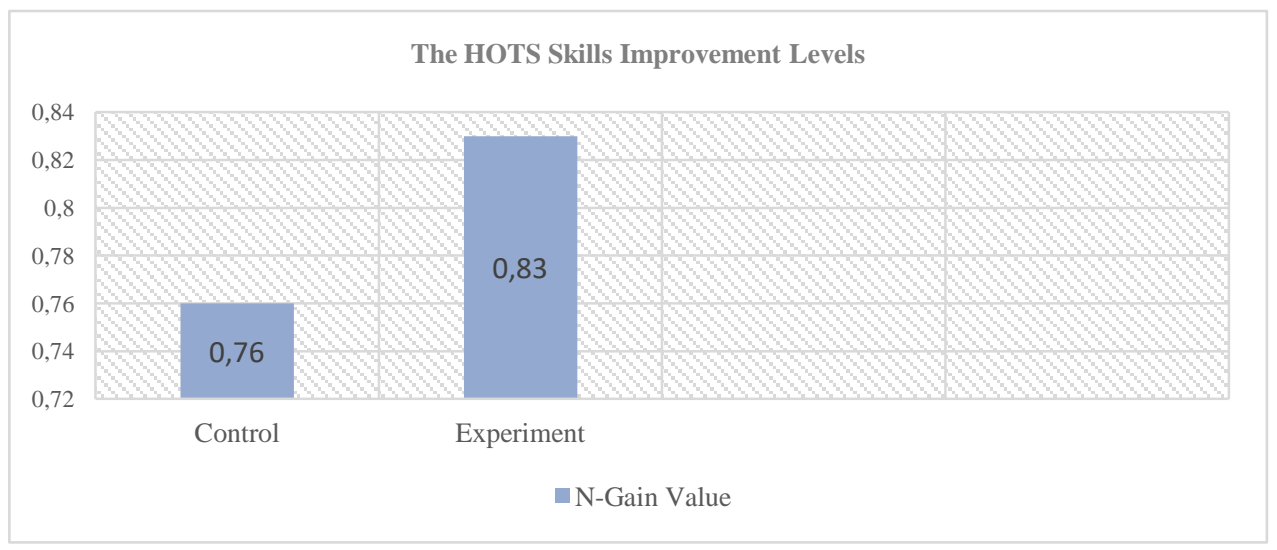

Figure 2. The HOTS improvement levels

Based on the improvement test results of the students' HOTS in the experimental class and the control class, it can be explained as follows: First, in the experimental class, it has the lowest and the highest pretest values of 38 and 65 , respectively, so that the range of these two values is 27 with an average value of 52.82 ; in the control class, the lowest pretest value is 30 and the highest is 66 so that the range is 46 with an average of 46.97 ; while, the lowest and the highest posttest values obtained in the experimental class are 55 and 75 , respectively, so that the range between the two values is 7 with an average of 71.57; in the control class, the lowest and the highest posttest values are 54 and 74, respectively, so the range between the two values is 20 with an average value of 68.38. Second, the experimental class has an average value with a difference of 18.75 . Third, the control class has an average pretest and posttest scores with a difference of 21.41. Fourth, the comparison of the difference in increased tolerance between the experimental class and the control class is 21.41: 18.75 with a difference of 2.66. Fifth, the significance value (2-tailed) of the experimental class is 0.000 .

Therefore, it can be concluded that the experimental class has sig value (2-tailed) of $<0.05$ which means that $\mathrm{H} 0$ is rejected i.e. there is a difference in the HOTS ability of students in the experimental class, before and after treatment. Meanwhile, the increase in the pretest and posttest scores of the experimental class is 0.83 with a high category whereas the control class is 0.76 with a moderate category. Based on the difference in the increase of HOTS ability in the experimental class and the control class, it proves that the SPPKB model is effective and has a positive influence on improving the students' HOTS in economic learning in the classroom.

\section{CONCLUSION}

The SPPKB model is a learning model that focuses on improving students' thinking skills through the study of facts or based on experience as material to solve proposed problems. Through the application of this model in 
economic learning in the classroom, it has proven effective in eliminating the impression that economic learning tends to be difficult and boring. The SPPKB is also effective for improving students' HOTS in economic learning. HOTS ability is one of the important competencies in the modern world of education, so they must be possessed by every student especially to be able to compete and adapt to the development of science and technology.

\section{REFERENCES}

Ahmad, I \& Sukiman. (2019). Analisis Higher Order Thinking Skills (HOTS) Pada Soal Ujian Akhir Siswa Kelas 6 KMI Dalam Kelompok Mata Pelajaran Dirasah Islamiyah Di Pondok Modern Tazakka Batang. Jurnal Pendidikan Agama Islam. Vol. XVI, No. 2, Desember 2019. Hlm. 137-164.

Astuti, R \& Suparno. (2017). Pengembangan Physics Comprehensive Contextual Teaching Materials Berbasis KKNI Untuk Meningkatkan HOTS Dan Menumbuhkan Kecerdasan Emosional. Universitas Muhammadiyah Metro: JPF (Jurnal Pendidikan Fisika). Vol. V. No. 1, Maret 2017. Hlm. 1-14.

Direktorat Jenderal Guru dan Tenaga Kependidikan. (2018). Buku Pegangan Pembelajaran Berorientasi Pada Keterampilan Berpikir Tingkat Tinggi. Jakarta: Kementerian Pendidikan dan Kebudayaan.

Ghazali, I. (2011). Aplikasi Analisis Multivariate dengan Program IBM SPSS19. Semarang: Badan Penerbit Universitas Diponegoro.

Heong, Y. M., Widad, J., Kiong, Tee Tze, Razali, M. (2011). The Level of Marzuno Higher Order Thinking Skills among Technical Education Students. International Journal of Social Science and Humanity. Vol. 1, No.2. Hlm 116-129

Marniawati. (2019). Peningkatan Higher Order Thinking Skills (HOTS) Melalui Strategi Pembelajaran Peningkatan Kemampuan Berpikir (SPPKB) Pada Pembelajaran Ekonomi. Jurnal Pendidikan Tambusai. Volume 3 Nomor 5 Tahun 2019. Hlm. 968-975.

Pratiwi, U \& Fasha, E. (2015). Pengembangkan Instrumen Penilaian HOTS Berbasis Kurikulum 2013 Terhadap Sikap Disiplin. Jurnal Penelitian dan Pembelajaran IPA (JPPI). Vol.1, No. 1, November 2015. Hlm. 123-142.

Priyatno, U. (2014). SPSS 22 Pengolahan Data Terpraktis. Yogykarta: CV. Andi Offset.

Putra, R \& Hanggara, A. (2018). Pengaruh Pendekatan Pembelajaran Saintifik Berorientasi Higher Order Thinking Skills (HOTS) Terhadap Pemahaman Belajar Siswa (Studi Kasus Pada Kelas X SMAN 1 Baregbeg). Equilibrium: Jurnal Penelitian dan
Pendidikan Ekonomi. Vol. 15. Issue 2, Desember 2018. Hlm. 44-50.

Sugiyono. (2015). Metode Penelitian Kuantitatif Kualitatif dan R\&D. Bandung: Alfabeta.

Sani, A. (2015). Pembelajaran Matematika Berbasis Pendekatan Saintifik Dan Kaitannya Dengan Menumbuhkan Keterampilan Berpikir Tingkat Tinggi. Yogyakarta: Seminar Nasional Matematika Dan Pendidikan Matematika UNY 2015. Hlm. 57-62.

Sanjaya, W. (2008). Strategi Pembelajaran Berorientasi Standar Proses Pendidikan. Jakarta: Kencana Prenada Media Group.

Yusuf, K. (2018). Penerapan Model Discovery Learning Untuk Meningkatkan Keterampilan HOTS Dan Prestasi Belajar IPA Siswa Kelas VII SMP Negeri 1 Garung Semester 1 Tahun Pelajaran 2017/2018. SPEKTRA: Jurnal Kajian Pendidikan Sains. Vol. IV No. 01, April 2018. Hlm. 41-48.

Zayyadi. (2014). Pengaruh Strategi Pembelajaran Peningkatan Kemampuan Berpikir Terhadap Hasil Belajar. INTERAKSI: Jurnal Kependidikan. Vol. 9. No. 1, Januari 2014. Hlm. 32-34. 